\title{
Evaluation of Contact Toxicity and Fumigant Effect of Some Medicinal Plant and Pirimiphos Methyl Powders against Cowpea Bruchid, Callosobruchus maculatus (Fab.) [Coleoptera: Chrysomelidae] in Stored Cowpea Seeds
}

\author{
K. D. Ileke (Corresponding author) \\ Department of Environmental Biology and Fisheries, Adekunle Ajasin University, \\ PMB 001, Akungba Akoko, Ondo State, Nigeria \\ Tel: 234-803-431-8706_E-mail: kayodeileke@yahoo.com
}

D. S. Bulus

Department of Food Science and Technology, Federal Polytechnic, Kaura Namoda, Zamfara State, Nigeria

Received: November 2, 2011

Accepted: November 14, $2011 \quad$ Online Published: February 2, 2012

doi: $10.5539 /$ jas.v4n4p279

URL: http://dx.doi.org/10.5539/jas.v4n4p279

\begin{abstract}
The contact toxicity and fumigant effect of Azadirachta indica A. Juss, Anacardium occidentale (L), Pipper guineense Schum and Thonn seeds powders and Pirimiphos methyl (Actellic) dust were evaluated against cowpea bruchid, Callosobruchus maculatus (Fab.). Contact toxicity assay show that $A$. indica and $P$. guineense powders have a comparative effect to synthetic insecticide, Pirimiphos methyl. Both were able to cause $100 \%$ mortality of $C$. maculatus at all tested concentrations $(0.1,0.2,0.4$ and $0.8 \mathrm{~g} / 20 \mathrm{~g}$ of cowpea seeds) within 7 days of post treatment. However, in the fumigation assay, none of the plant powders was suitable as a fumigant since A. indica and $P$. guineense powders could only cause $23.3 \%$ and $20 \%$ mortality of adult cowpea bruchid respectively after 7 days of application. Pirimiphos methyl powder was good as a fumigant causing $100 \%$ mortality of $C$. maculatus after 7 days of application at all tested concentrations.
\end{abstract}

Keywords: Cowpea seed, Callosobruchus maculatus, Azadirachta indica, Anacardium occidentale, Pipper guineense, Pirimiphos methyl, Biopesticide

\section{Introduction}

Food legumes occupy a prominent place in the diets of many people worldwide. Their edible seeds form a cheap source of high protein diets (Okosun and Adedire, 2010). The cowpea bruchid, Callosobruchus maculatus, a major insect pest of cowpea in the tropics (Ofuya, 1992) causes great loss of stored cowpea seeds in Nigeria (Caswell. 1970; Taylor, 1971).

Control of field-to-store insect pest like C. maculatus has centred mainly on the use of synthetic insecticides and fumigants (Oni and Ileke, 2008; Ashamo, 2010;). This has led to problems such as unavailability of pesticides at critical periods, development of resistant insect strains, and toxicity to the end users (Akinkurolere et al., 2006; Oni and Ileke, 2008; Adedire et al., 2011; Ileke and Oni, 2011; Oni, 2011). Research is ongoing for natural plant materials that are ecofriendly, biodegradable, and with medicinal values that may be used as grains protectant (Adedire and Lajide, 2003; Arannilewa et al., 2006; Ileke and Oni, 2011). The use of plant powders to protect harvested grains against insect pests has been an ancient practice. Many plants, including spices had been reported to have insecticidal properties by many researchers (Ivbijaro and Agbaje, 1986; Adedire and Lajide, 2003; Ashamo, 2004; 2007; Oni and Ileke, 2008).

This present study evaluated the efficacy of three medicinal plant products compared with Pirimiphos methyl (Actellic) powders against cowpea bruchid, C. maculatus. This investigation also examined the method of application of these plant products powders. 


\section{Materials and Methods}

This study was conducted at the Environmental Biology and Fisheries Research Laboratory, Adekunle Ajasin University, Akungba Akoko, Ondo State, Nigeria.

\subsection{Insect Culture}

Adult cowpea bruchid, C. maculatus was obtained from established laboratory culture reared on disinfested cowpea seeds, Vigna unguiculata (L.) Walp variety Ife brown at ambient temperature of $28 \pm 2^{\circ} \mathrm{C}$ and $75 \pm 5 \%$ relative humidity. The cowpea seeds used for bioassay was obtained from Agricultural Development Project, Ikole Ekiti, Ekiti State, Nigeria and these were firstly cleaned and disinfested by keeping at $-5^{\circ} \mathrm{C}$ for 7 days to kill all hidden infestations. This is because all the life stages, particularly the eggs are very sensitive to cold (Koehler, 2003). The disinfested cowpea seeds were then placed inside a Gallenkamp oven (Model 250) at $40^{\circ} \mathrm{C}$ for 4 hours (Jambere et al., 1995) and later air dried in the Laboratory to prevent mouldiness (Adedire et al., 2011 ) before they were stored in plastic containers with tight lids disinfested by swabbing with $90 \%$ alcohol.

\subsection{Plant Materials}

The plant materials used in the present study include Azadirachta indica, Anacardium occidentale and Piper guineense seeds. These materials were sourced fresh from Akola farm at Igbara-Odo Ekiti, Ekiti State, Nigeria. The plants were sun dried for 3 to 7 days. The cleaned dried plants were pulverised into fine powders using a blender (Supermaster ${ }^{\circledR}$, Model SMB 2977, Japan). The powders were further sieved to pass through $1 \mathrm{~mm}^{2}$ mesh. The powders were packed in plastic containers with tight lids and stored in a refrigerator at $4^{\circ} \mathrm{C}$ prior to use.

\subsection{Effect of Contact Toxicity of Plants Products and Pirimiphos methyl Powders on Adult Mortality of C.} maculatus

The plant powders were thoroughly mixed with $20 \mathrm{~g}$ of cowpea seeds in $250 \mathrm{ml}$ plastic containers at 0.0 (control), $0.2,0.4$ and $0.8 \mathrm{~g}$ concentrations. Similarly, 0.0 (control), $0.2,0.4$ and $0.8 \mathrm{~g}$ of Pirimiphos methyl dust obtained from Agro Chemical store for comparison were mixed with $20 \mathrm{~g}$ of cowpea seeds inside $250 \mathrm{ml}$ plastic containers. The experiments were set up in a Completely Randomized Design (CRD) and each treatment was replicated three times. Ten pairs of adult $C$. maculatus unsexed ( 2 to 3 days old) were introduced into the treated and control (Idoko and Adebayo, 2011; Udo, 2011). Bruchid mortality was assessed every 24 hours for three days, then at 7 days after treatment (Ashamo, 2007).

\subsection{Fumigant Effect of Plants Products and Pirimiphos methyl Powders on Adult Mortality of C. maculatus}

Ten grammes of the cowpea seeds were weighed into $50 \mathrm{ml}$ plastic film tubes that had been cut opened at the bottom and sealed with mushlin cloth. Plant powders weighing 0.0 (untreated), $0.2,0.4$ and $0.8 \mathrm{~g}$ were put into another half-cut $50 \mathrm{ml}$ plastic film tubes. The $50 \mathrm{ml}$ tube and $25 \mathrm{ml}$ tube were then joined together with the aid of gum in corresponding orders. Ten pairs of unsexed adult $C$. maculatus ( 2 to 3 days old) were introduced to the tube containing $10 \mathrm{~g}$ of cowpea seeds and tight sealed. The experiments were set up in a Completely Randomized Design (CRD) and each treatment was replicated three times. Bruchid mortality was assessed every 24 hours for three days, then at 7 days after treatment (Ashamo, 2007).

\subsection{Statistical Analysis}

Data were subjected to analysis of variance. Where significant differences existed, treatment means were separated using the New Duncan's Multiple Range Test (Zar, 1984).

\section{Results}

\subsection{Effectiveness of Plants and Pirimiphos methyl Powders as Contact Insecticides}

The contact toxicity of $A$. indica, A. occidentale, $P$. guineense and pirimiphos methyl powders against $C$. maculatus are show in Table 1 . Neem, A. indica powder caused $50 \%$ mortality of adult cowpea bruchid, $C$. maculatus at rate of $0.8 \mathrm{~g} / 20 \mathrm{~g}$ within 24 hours of post treatment. The corresponding value for $P$. guineense was $47.7 \%$ mortality. These were significantly lower $(\mathrm{P}<0.05)$ than that of pirimiphos methyl dust which caused $77.7 \%$ mortality of adult cowpea bruchid, C. maculatus at rate of $0.8 \mathrm{~g} / 20 \mathrm{~g}$ of cowpea seeds within 24 hours of application. At three days post treatment, $A$. indica, A. occidentale and $P$. guineense caused $93.3 \%, 43.3 \%$ and $90 \%$ mortality of adult cowpea bruchid, C. maculatus at rate of $0.8 \mathrm{~g} / 20 \mathrm{~g}$ of cowpea seeds compared with pirimiphos methyl who were able to evoked $100 \%$ adult mortality of $C$. maculatus at all the concentrations tested. However at seven days post application, A. indica, P. guineense and pirimiphos methyl powders caused $100 \%$ mortality of adult bruchid at all tested concentrations. 


\subsection{Fumigant Effect of Plant and Pirimiphos Methyl Powders}

Table 2 shows the fumigant effect of $A$. indica, $A$. occidentale, $P$. guineense and pirimiphos methyl powders against $C$. maculatus. At three days of application, powders of $A$. indica, $A$. occidentale and $P$. guineense caused mortality of adult cowpea bruchid at all tested concentrations. However pirimiphos methyl powder caused $100 \%$ mortality of adult $C$. maculatus at all tested concentrations.

\section{Discussion}

Neem, A. indica powder when used as contact insecticides caused $100 \%$ mortality of adult bruchid within 7 days of treatment, an effect that have earlier been reported by Ofuya (1992); Onu and Baba (2003); Mainia and Lale (2004); Mbailao et al. (2006). The insecticidal potential of $A$. indica could be attributed to the presence of azadiratins, which is toxic to stored product insect pests (Onu and Baba, 2003; Mainia and Lale, 2004; Mbailao et al., 2006).

Black pepper, $P$. guineense powder also had contact toxicity of comparable effect to that of pirimiphos methyl dust causing $100 \%$ adult mortality of bruchid within 7 days of application, an effect that is similar to the report of Adedire and Lajide (2003) that extract of $P$. guineense adversely affected the survival of Sitophilus zeamais. This result also validated the reports of Asawalam and Emosairue (2006); Ashamo (2007) that P. guineense and Pirimiphos methyl powders caused $100 \%$ mortality of adult maize weevil within 7 days of application. These authors established that the biological activity of $P$. guineense could be attributed to the presence of chavin and piperine, an unsaturated amide (Lale, 1992). Ofuya and Dawodu (2002) also reported the effectiveness of $P$. guineense powder against $C$. maculatus.

Cashew seed powder could be very effective against stored product insects if applied at high concentrations. Oparaeke and Bunmi (2006) reported that A. occidentale nut shell was highly toxic to C. subinnotatus and achieved $100 \%$ insect mortality within 48 hours at $7.5 \%$ and $100 \%$ mortality within 72 hours at $2.5 \%$ and $5.0 \%$ concentrations. Adedire et al. (2011) also reported that cashew kernel extracted with water, methanol, ethanol, acetone, pet- ether and n-hexane caused $85 \%$ to $100 \%$ adult mortality of $C$. maculatus. They attributed these insecticidal activities to the presence of secondary plant compounds such as anacardic acid and cardinal (Rehn and Espig, 1991). Others are quercetin and kampferol glycosides (Oliver- Bever, 1986).

In this study, the lethal effect of these powders on cowpea bruchid could be as a result of contact toxicity. Most insects breathe by means of trachea which usually opens at the surface of the body through spiracles (Adedire $e t$ al., 2011). These spiracle might have been blocked by the powders thereby leading to suffocation of the insects.

The plants powders were not effective as fumigants with the highest mortality of $23.3 \%$ and $20 \%$ caused by $A$. indica and $P$. guineense powders respectively. This result validated the report of Ashamo (2007) who recorded that $P$. guineense powders tested for fumigant effect could only caused $28.4 \%$ adult mortality of maize weevil.

\section{Conclusion and Recommendation}

Results obtained from this study revealed the potentials of $A$. indica and $P$. guineense seeds powders as plant derived insecticides against cowpea bruchid, C. maculatus. The medicinal values, availability, biodegradable, low costs rate and potential as biopesticide make them candidates in upgrading traditional crop protection practices in sub-Saharan Africa.

\section{Acknowledgments}

The authors are grateful to all the Technologists in the Department of Environmental Biology and Fisheries as well as Department of Plant Science and Biotechnology, Adekunle Ajasin University, Akungba Akoko, Ondo State, Nigeria for their technical assistance.

\section{References}

Adedire, C.O \& Lajide, L. (2003). Ability of extracts of ten tropical plant species to protect maize grains against infestation by the maize weevil Sitophilus zeamais during storage. Nigerian Journal Experimental Biology, 4(2), 175-179.

Adedire, C.O., Obembe, O. O., Akinkurolele, R. O. \& Oduleye, O. (2011). Response of Callosobruchus maculatus (Coleoptera: Chysomelidae: Bruchinae) to extracts of cashew kernels. Journal of Plant Diseases and Protection, 118(2), 75-79.

Akinkurolele, R. O., Adedire, C. O. \& Odeyemi, O. O. (2006). Laboratory evaluation of the toxic properties of forest anchomanes, Anhomanes difformis, against pulse beetle, Callosobruchus maculatus (Coleoptera: Bruchidae). Insect Science, 13, 25-29. http://dx.doi.org/10.1111/j.1744-7917.2006.00064.x 
Arannilewa S. T.; Ekrakene, T. \& Akinneye, J. O. (2006). Laboratory evaluation of four medicinal plants as protection against the maize weevil, Sitophilus zeamais. African Journal of Biotechnology, 5(21), 2032-2036.

Asawalam, M. O. \& Emosairue, S. O. (2006). Comparative efficacy of Pipper guineense powder and pirimiphos methyl dust against Sitophilus zeamais in stored maize. Nigerian Journal of Entomological Society, 23, 30 - 33.

Ashamo, M. O. (2004). Effect of some plants powders on the yam moth, Dasyses rugosella. Bioscience Research Communications, 16(1), $41-46$.

Ashamo, M. O. (2007). Evaluation of contact toxicity and fumigant effect of some plant powders against Sitophilus zeamais. Proceeding, Akure Hambold Kellog/ $3^{\text {rd }}$ SAAT Annual Conference, Federal University of Technology, Akure, Nigeria. 3, $64-67$.

Caswell, G. H. (1970). The storage of cowpea in the Northern States of Nigeria. Samaru Research Bulletin, 120, $4-6$.

Idoko, J. E. \& Adebayo, R. A. (2011). Efficacy of single and combined leaf powder of Nicotiana tabacum L.[Solanales: Solanaceaee] with reduced rates of Pirimiphos methyl in management of Sitophilus zeamais Motschulsky [Coleoptera: Curculionidae]. Journal of Agriculture Science, 3(1), 276 - 280.

Ileke, K. D. \& Oni, M. O. (2011). Toxicity of some plant powders to maize weevil, Sitophilus zeamais (Coleoptera: Curculionidae) on stored wheat grains. African Journal of Agricultural Research, 6(13), 3043-3048.

Ivbijaro, M. F. \& Agbaje, M. (1986). Insecticidal activities of Piper guineense and Capsicum species in cowpea bruchid, Callosobruchus maculatus. Insect Science and its Application, 7, 521-524.

Jambere, B., Obeng - Ofori, D. \& Hassanali, A. (1995). Products derived from the leaves of Ocimum kilmandsharicum as post harvest grain protestant against the infection of three major stored insect product pests. Bulletin of Entomological Research, 85, 351-367.

Koehler, P. G. (2003). Biopesticides (Volume 2). Entomology and Nematology Department, University of Florida, Gainesuilla 326pp.

Lale, N.E.S. (1992). A laboratory study of the comparative toxicity of products from three spices to the maize weevil. Postharvest Biology Technology, 2, 61 - 64. http://dx.doi.org/10.1016/0925-5214(92)90028-N

Maina, Y. T. \& Lale, N.E.S. (2004). Efficacy of integrating varietal resistance and neem (Azadirachta indica) seed oil for the management of Callosobruchus maculatus infesting Bambara Groundnut in storage in storage. Nigerian Journal of Entomological Society, 2, 94 - 103.

Mbailao, M., Nanadoum, M, Automne, B., Gabra, B. \& Emmanuel, A. (2006). Effect of six common seed oils on survival, egg lying and development of the cowpea weevil, Callosobruchus maculatus. Journal of Biological Sciences, 6 (2), 420 -425. http://dx.doi.org/10.3923/jbs.2006.420.425

Ofuya, T. I. (1992). Oviposition deterrence and ovicidal properties of some plant powders against C. maculatus in stored cowpea seeds. Journal of Agricultural Sciences, $115,343-345$. http://dx.doi.org/10.1017/S0021859600075766

Ofuya, T. I. \& Dawodu, E. O. (2002). Aspect of insecticidal action of Pipper guineense powders against Callosobruchus maculatus. Nigerian Journal of Entomological Society, 19, 40 - 50.

Okosun O. O. \& Adedire C. O. (2010). Potency to cowpea seed bruchid, Callosobruchus maculatus of African Nutmeg seed, Monodora myristica extracted with different solvents. Nigerian Journal of Entomological Society, 27, 89-95.

Oliver- Bever, B. (1986). Medicinal plants in tropical West Africa. Cambridge University Press, Cambridge, United Kingdom.

Oni, M. O. (2011). Evaluation of seed and fruit powder of Capsicum annum and C. frutescens for control of Callosobruchus maculatus (Fab.) in stored cowpea and Sitophilus zeamais in stored maize. International Journal of Biology, 3(2), 185-188. http://dx.doi.org/10.5539/ijb.v3n2p185

Oni, M.O. \& Ileke, K. D. (2008). Fumigant toxicity of four botanical plant oils on survival, egg laying and progeny development of the dried yam beetle, Dinoderus porcellus (Coleoptera: Bostrichidae). Ibadan Journal of Agricultural Research, 4 (2), 31-36.

Onu, I. \& Baba, G.O. (2003). Evaluation of Neem products for the control of Dermestid beetle on dried fish. Nigerian Journal of Entomological Society, 20, $105-115$. 
Oparaeke, A. M. \& Bunmi, O. J. (2006): Insecticidal potential of cashew, Anarcadium occidentale for control of the beetle, Callosobruchus subinnotatus on bambara groundnut. Archives of Phytopathology and Plant Protection, 39(4), 247-251. http://dx.doi.org/10.1080/03235400500094431

Rehn, S. \& Espig, G. (1991). The Cultivated Plants of the Tropics and Subtropics. Cultivation, Economic Value, Utilization. Verlag Josef Margraf Scientific Books, CTA, 522pp.

Taylor, T (1971). The flight activity of curculionidae and some other grain infesting beetles in the field and in a store. Journal of Stored Products Research, 6:295-306. http://dx.doi.org/10.1016/0022-474X(71)90042-7

Udo, I. O. (2011). Potential of Zanthoxylum xanthoxyloides (Lam.) for the control of stored product insect pests. Journal of Stored Products and Postharvest Research, 2(3): 40 - 44.

Zar, J. H. (1984). Biostatatical Analysis, $2^{\text {nd }}$ ed, Prentice- Hall International, Englewood Cliffs, N. J.

Table 1. Comparison of percentage mortality of adult $C$. maculatus in cowpea seeds treated with plants powders and Pirimiphos methyl dust for contact toxicity

\begin{tabular}{|c|c|c|c|c|c|}
\hline \multirow[t]{2}{*}{ Plant powder } & \multirow[t]{2}{*}{ Conc. g/20g Cowpea } & \multicolumn{4}{|c|}{ Mean \% Mortality at days Post treatment \pm S.E. } \\
\hline & & 1 & 2 & 3 & 7 \\
\hline \multirow[t]{4}{*}{ A. indica } & 0.1 & $10.0 \pm 0.0 \mathrm{ab}$ & $30.0 \pm 0.0 \mathrm{~b}$ & $67.7 \pm 0.3 d$ & $100.0 \pm 0.0 \mathrm{~d}$ \\
\hline & 0.2 & $14.7 \pm 0.6 b$ & $46.3 \pm 0.6 \mathrm{c}$ & $70.0 \pm 0.0 \mathrm{~d}$ & $100.0 \pm 0.0 \mathrm{~d}$ \\
\hline & 0.4 & $20.0 \pm 0.0 \mathrm{~b}$ & $54.7 \pm 0.3 c$ & $84.4 \pm 0.2 \mathrm{e}$ & $100.0 \pm 0.0 \mathrm{~d}$ \\
\hline & 0.8 & $50.0 \pm 0.0 \mathrm{c}$ & $79.3 \pm 0.4 d$ & $93.3+0.6 \mathrm{ef}$ & $100.0 \pm 0.0 \mathrm{~d}$ \\
\hline \multirow[t]{4}{*}{ A. occidentale } & 0.1 & $0.0 \pm 0.0 \mathrm{a}$ & $0.0 \pm 0.0 \mathrm{a}$ & $20.0 \pm 0.0 \mathrm{~b}$ & $47.3 \pm 0.6 b$ \\
\hline & 0.2 & $0.0 \pm 0.0 \mathrm{a}$ & $0.0 \pm 0.0 \mathrm{a}$ & $27.3+0.6 b c$ & $53.3+0.6 b c$ \\
\hline & 0.4 & $0.0+0.0 \mathrm{a}$ & $0.0 \pm 0.0 \mathrm{a}$ & $33.7+0.3 \mathrm{c}$ & $60.0+0.0 \mathrm{c}$ \\
\hline & 0.8 & $0.0+0.0 \mathrm{a}$ & $0.0+0.0 \mathrm{a}$ & $43.3+0.6 \mathrm{c}$ & $63.3+0.6 \mathrm{c}$ \\
\hline \multirow[t]{4}{*}{ P. guineense } & 0.1 & $10.0 \pm 0.0 \mathrm{ab}$ & $30.0 \pm 0.0 \mathrm{~b}$ & $63.3 \pm 0.6 \mathrm{~d}$ & $100.0 \pm 0.0 \mathrm{~d}$ \\
\hline & 0.2 & $12.3 \pm 0.6 b$ & $44.2 \pm 0.2 \mathrm{c}$ & $67.7 \pm 0.3 \mathrm{~d}$ & $100.0 \pm 0.0 \mathrm{~d}$ \\
\hline & 0.4 & $19.7 \pm 0.3 b$ & $50.0 \pm 0.0 \mathrm{c}$ & $83.3 \pm 0.6 \mathrm{e}$ & $100.0 \pm 0.0 \mathrm{~d}$ \\
\hline & 0.8 & $46.7 \pm 0.3 \mathrm{c}$ & $76.7 \pm 0.3 \mathrm{~d}$ & $90.0 \pm 0.0 \mathrm{ef}$ & $100.0 \pm 0.0 \mathrm{~d}$ \\
\hline \multirow[t]{4}{*}{ Pirimiphos methyl } & 0.1 & $63.3 \pm 0.6 \mathrm{~d}$ & $80.0+0.0 \mathrm{~d}$ & $100.0 \pm 0.0 \mathrm{f}$ & $100.0 \pm 0.0 \mathrm{~d}$ \\
\hline & 0.2 & $67.7 \pm 0.3 \mathrm{de}$ & $83.3 \pm 0.6 \mathrm{de}$ & $100.0 \pm 0.0 \mathrm{f}$ & $100.0 \pm 0.0 \mathrm{~d}$ \\
\hline & 0.4 & $70.0+0.0 \mathrm{de}$ & $87.7+0.3 \mathrm{e}$ & $100.0+0.0 \mathrm{f}$ & $100.0+0.0 \mathrm{~d}$ \\
\hline & 0.8 & $77.7 \pm 0.3 \mathrm{e}$ & $90.0+0.0 \mathrm{e}$ & $100.0+0.0 \mathrm{f}$ & $100.0+0.0 \mathrm{~d}$ \\
\hline Control & 0.0 & $0.0+0.0 \mathrm{a}$ & $0.0+0.0 \mathrm{a}$ & $0.0+0.0 \mathrm{a}$ & $0.0 \pm 0.0 \mathrm{a}$ \\
\hline
\end{tabular}

Each value is a mean of \pm standard error of three replicates. Means within the same column followed by the same letter(s) are not significantly different at $(\mathrm{P}>0.05)$ from each other using New Duncan Multiple Range Test. 
Table 2. Comparison of percentage mortality of adult C. maculatus in cowpea seeds treated with plants powders and Pirimiphos methyl dust for fumigant effect

\begin{tabular}{|c|c|c|c|c|c|}
\hline \multirow[t]{2}{*}{ Plant powder } & \multirow[t]{2}{*}{ Conc. g/20g Cowpea } & \multicolumn{4}{|c|}{ Mean $\%$ Mortality at days Post treatment \pm S.E. } \\
\hline & & 1 & 2 & 3 & 7 \\
\hline \multirow[t]{4}{*}{ A. indica } & 0.1 & $0.0 \pm 0.0 \mathrm{a}$ & $0.0 \pm 0.0 \mathrm{a}$ & $0.0 \pm 0.0 \mathrm{a}$ & $0.0 \pm 0.0 \mathrm{a}$ \\
\hline & 0.2 & $0.0 \pm 0.0 \mathrm{a}$ & $0.0 \pm 0.0 \mathrm{a}$ & $0.0 \pm 0.0 \mathrm{a}$ & $0.0 \pm 0.0 \mathrm{a}$ \\
\hline & 0.4 & $0.0 \pm 0.0 \mathrm{a}$ & $0.0 \pm 0.0 \mathrm{a}$ & $0.0 \pm 0.0 \mathrm{a}$ & $10.0 \pm 0.0 \mathrm{a}$ \\
\hline & 0.8 & $0.0 \pm 0.0 \mathrm{a}$ & $0.0 \pm 0.0 \mathrm{a}$ & $0.0 \pm 0.0 \mathrm{a}$ & $23.3 \pm 0.6 b$ \\
\hline \multirow[t]{4}{*}{ A. occidentale } & 0.1 & $0.0 \pm 0.0 \mathrm{a}$ & $0.0 \pm 0.0 \mathrm{a}$ & $0.0 \pm 0.0 \mathrm{a}$ & $0.0 \pm 0.0 \mathrm{a}$ \\
\hline & 0.2 & $0.0 \pm 0.0 \mathrm{a}$ & $0.0 \pm 0.0 \mathrm{a}$ & $0.0 \pm 0.0 \mathrm{a}$ & $0.0 \pm 0.0 \mathrm{a}$ \\
\hline & 0.4 & $0.0+0.0 \mathrm{a}$ & $0.0 \pm 0.0 \mathrm{a}$ & $0.0+0.0 \mathrm{a}$ & $0.0 \pm 0.0 \mathrm{a}$ \\
\hline & 0.8 & $0.0+0.0 \mathrm{a}$ & $0.0+0.0 \mathrm{a}$ & $0.0+0.0 \mathrm{a}$ & $0.0+0.0 \mathrm{a}$ \\
\hline \multirow[t]{4}{*}{ P. guineense } & 0.1 & $0.0+0.0 \mathrm{a}$ & $0.0 \pm 0.0 \mathrm{a}$ & $0.0+0.0 \mathrm{a}$ & $0.0 \pm 0.0 \mathrm{a}$ \\
\hline & 0.2 & $0.0 \pm 0.0 \mathrm{a}$ & $0.0 \pm 0.0 \mathrm{a}$ & $0.0 \pm 0.0 \mathrm{a}$ & $0.0 \pm 0.0 \mathrm{a}$ \\
\hline & 0.4 & $0.0 \pm 0.0 \mathrm{a}$ & $0.0 \pm 0.0 \mathrm{a}$ & $0.0 \pm 0.0 \mathrm{a}$ & $0.0 \pm 0.0 \mathrm{a}$ \\
\hline & 0.8 & $0.0 \pm 0.0 \mathrm{a}$ & $0.0 \pm 0.0 \mathrm{a}$ & $0.0 \pm 0.0 \mathrm{a}$ & $20.0 \pm 0.0 \mathrm{~b}$ \\
\hline \multirow[t]{4}{*}{ Pirimiphos methyl } & 0.1 & $10.0 \pm 0,0 \mathrm{a}$ & $53.3 \pm 0.6 \mathrm{~b}$ & $100.0 \pm 0.0 \mathrm{~b}$ & $100.0 \pm 0.0 \mathrm{c}$ \\
\hline & 0.2 & $23.3 \pm 0.6 b$ & $60.0 \pm 0.0 \mathrm{bc}$ & $100.0 \pm 0.0 \mathrm{~b}$ & $100.0 \pm 0.0 \mathrm{c}$ \\
\hline & 0.4 & $30.0 \pm 0.0 \mathrm{bc}$ & $67.7 \pm 0.3 \mathrm{~cd}$ & $100.0 \pm 0.0 \mathrm{~b}$ & $100.0 \pm 0.0 \mathrm{c}$ \\
\hline & 0.8 & $37.7 \pm 0.3 \mathrm{c}$ & $77.7 \pm 0.3 \mathrm{~d}$ & $100.0 \pm 0.0 \mathrm{~b}$ & $100.0 \pm 0.0 \mathrm{c}$ \\
\hline Control & 0.0 & $0.0 \pm 0.0 \mathrm{a}$ & $0.0 \pm 0.0 \mathrm{a}$ & $0.0 \pm 0.0 \mathrm{a}$ & $0.0 \pm 0.0 \mathrm{a}$ \\
\hline
\end{tabular}

Each value is a mean of \pm standard error of three replicates. Means within the same column followed by the same letter(s) are not significantly different at $(\mathrm{P}>0.05)$ from each other using New Duncan Multiple Range Test. 